\title{
PENGGUNAAN EJAAN BAHASA INDONESIA PADA MAKALAH MAHASISWA
}

\author{
Hera Wahdah Humaira ${ }^{1}$ \\ Universitas Muhammadiyah Sukabumi \\ hera297@ummi.ac.id \\ Asep Firdaus ${ }^{2}$ \\ Universitas Muhammadiyah Sukabumi \\ asepfirdaus@ummi.ac.id
}

\begin{abstract}
ABSTRAK
Penelitian ini memiliki tujuan untuk menguji penggunaan ejaan bahasa Indonesia yang digunakan serta untuk mengklasifikasikan bentuk kesalahan ejaan bahasa Indonesia yang digunakan. Data dalam penelitian ini yaitu kesalahan ejaan pada makalah mahasiswa program studi Pendidikan Bahasa dan Sastra Indonesia. Sumber data penelitian ini yaitu makalah mahasiswa program studi Pendidikan Bahasa dan Sastra Indonesia. Teknik pengumpulan data penelitian ini menggunakan teknik catat yaitu peneliti mencatat kutipan data yang berkaitan dengan kesalahan ejaan pada makalah mahasiswa. Teknik analisis data menggunakan teknik reduksi data, penyajian data dan penarikan simpulan. Peneliti menganalisis data penelitian yaitu 10 makalah yang sudah dibuat oleh mahasiswa prodi PBSI UMMI tahun 2014 pada mata kuliah membaca. Hasil penelitian yaitu bentuk-bentuk kesalahan ini terdapat pada 10 makalah dan masuk kepada 9 jenis kesalahan yaitu jenis kesalahan penggunaan huruf kapital, hilangnya tanda baca, tidak ada spasi setelah tanda baca, kesalahan penulisan kata berimbuhan, hilangnya vokal dan konsonan, kesalahan penulisan kata asing, penggunaan kata depan, penulisan kata partikel dan penulisan huruf miring. Oleh karena itu sangat penting bagi seluruh lapisan masyarakat seperti siswa, mahasiswa, guru, dosen untuk mempelajari dan menguasai ejaan bahasa Indonesia yang terdapat dalam pedoman umum ejaan bahasa Indonesia (PUEBI)
\end{abstract}

Kata kunci:Ejaan, Makalah, Mahasiswa

\section{A. PENDAHULUAN}

Manusia sebagai makhluk sosial, membutuhkan bahasa sebagai alat untuk menjalin komunikasi antar individu. Oleh karena itu, perlu mengetahui bagaimana menggunakan kalimat yang benar dalam komunikasi verbal maupun tulisan agar penutur dapat menyampaikan maksudnya dengan baik pada lawan tutur. Semua manusia, dari mana pun dia berasal tentu mempunyai bahasa. Begitu mendasar berbahasa ini bagi manusia, sama halnya seperti bernafas yang begitu mendasar dan perlu dalam hidup manusia. Jika kita tidak mempunyai bahasa, maka kita akan kehilangan kemanusiaan kita. Kita tidak lagi dapat berfungsi sebagai makhluk yang berpengetahuan. Bahasa sebagai alat komunikasi memiliki tujuan-tujuan yang ingin dicapai. Tarigan (seorang pencetus) mengemukakan bahwa pada prinsipnya, tujuan pembelajaran bahasa adalah agar siswa terampil berbahasa, yaitu terampil menyimak, terampil berbicara, terampil membaca, dan terampil menulis. Keterampilan 


\section{Lingua Rima: Jurnal Pendidikan Bahasa dan Sastra Indonesia \\ Vol. 10 No. 3 September 2021 \\ http://jurnal.umt.ac.id/index.php/lgrm}

menulis adalah keterampilan yang paling sulit daripada keterampilan berbahasa yang lainnya. Oleh sebab itu perlu kehati-hatian dalam menulis kalimat, agar sesuai dengan ejaan bahasa Indonesia. Seorang mahasiswa dalam bangku perkuliahan telah diajarkan bagaimana harus menulis sebuah karangan yang baik terutama ketika menulis karya ilmiah. Karangan yang ditulis pun harus sesuai dengan ejaan bahasa Indonesia, kalimatnya pun harus sesuai dengan pedoman umum ejaan bahasa Indonesia (PUEBI).

Sebuah karya ilmiah disusun dengan memanfaatkan bahasa tulis. Kalimat dalam karya ilmiah hendaknya menggunakan bahasa indonesia baku. Penggunaan bahasa indonesia baku dalam karya ilmiah hendaknya tidak terlepas dari hakikat sebuah karya ilmiah yang merupakan bagian dari karya keilmuwan. Kegiatan menulis di perguruan tinggi memiliki persyaratan yang harus dipenuhi. Tulisan yang baik mempunyai beberapa ciri, diantaranya bermakna, jelas/lugas, merupakan kesatuan yang bulat, singkat dan padat, serta memenuhi kaidah Penulisan Umum Ejaan Bahasa Indonesia. Menurut Siswoyo (2007: 121) mahasiswa dapat didefinisikan sebagai individu yang sedang menuntut ilmu ditingkat perguruan tinggi, baik negeri maupun swasta atau lembaga lain yang setingkat dengan perguruan tinggi. Mahasiswa dinilai memiliki tingkat intelektualitas yang tinggi, kecerdasan dalam berpikir dan kerencanaan dalam bertindak. Berpikir kritis dan bertindak dengan cepat dan tepat merupakan sifat yang cenderung melekat pada diri setiap mahasiswa, yang merupakan prinsip yang saling melengkapi. Mahasiswa pada saat menulis makalah harus memperhatikan ejaan bahasa Indonesia. Kesalahan ejaan bahasa Indonesia seringkali terdapat pada penulisan beberapa makalah mahasiswa. Mereka cenderung melakukan kesalahan dalam penulisan ejaan bahasa Indonesia seperti tanda baca atau huruf kapital sehingga rendahnya kualitas karya ilmiah. Mahasiswa pada saat dibangku sekolah menengah atas sudah sering kali ditugaskan membuat makalah dan menjadi rutinitas biasa akan tetapi apakah kebiasaan dan pemahaman ejaan bahasa Indonesia mahasiswa sama atau lebih baik dalam menulis makalah ketika menjadi mahasiswa. Berdasarkan hal-hal yang telah dikemukakan tersebut, maka tujuan penelitian 1) untuk menguji penggunaan ejaan bahasa Indonesia yang digunakan, 2) untuk mengklasifikasikan bentuk kesalahan ejaan bahasa Indonesia yang digunakan.

Wijayanti dkk (2014: 1) mengatakan bahwa ejaan adalah kaidah cara menggambarkan/melambangkanbunyi-bunyi tuturan (kata, kalimat, dan sebagainya) dan bagaimana hubungan diantara lambang-lambang(pemisahan dan penggabungannya dalam suatu bahasa). Hal yang lain menurut Gantamitreka, (2016:9), ejaan adalah kaidah-kaidah cara penggambaran bunyi-bunyi (kata, kalimat, dan sebagainya) dalam bentuk tulisan (huruf- 


\section{Lingua Rima: Jurnal Pendidikan Bahasa dan Sastra Indonesia \\ Vol. 10 No. 3 September 2021 \\ http://jurnal.umt.ac.id/index.php/lgrm}

huruf) serta penggunaan tanda baca. Pendapat yang sama Menurut Suyanto (2011: 90) Ejaan adalah sebuah ilmu yang mempelajari bagaimana ucapan atau apa yang di-lisankan oleh seseorang ditulis dengan perantara lambang- lambang atau gambar-gambar bunyi. Oleh karena itu dari beberapa pengertian di atas mengenai ejaan bahwa ejaan merupakan penggambaran kata, kalimat dan sebagainya yang dituliskan atau apa yang dilisankan oleh seseorang.

Ejaan yang Disempurnakan adalah ejaan bahasa Indonesia yang berlaku sejak tahun 1972. Ejaan ini menggantikan ejaan sebelumnya, Ejaan Republik atau Ejaan Soewandi. Ejaan bahasa Indonesia Yang Disempurnakan berlaku sejak 1972 sampai 2015. Namun, kenyataanya menunjukkan bahwa sampai kurun 2015 tersebut masih sering dijumpai tulisan yang tidak taat asas atau menyimpang dari ketentuan yang telah ditetapkan. Hal tersebut mengakibatkan lahirnya pedoman yang baru yaitu menjadi Pedoman Umum Ejaan Bahasa Indonesia (PUEBI). PUEBI terlahir dengan harapan sebagai penyempurna dari ejaan sebelumnya. Perubahan yang dilakukan oleh Badan Pengembangan dan Pembinaan Bahasa Indonesia ini, berlandaskan Peraturan Menteri dan Kebudayaan RI Nomor 50 Tahun 2015.

Mahasiswa tidak dapat dipisahkan dengan karya ilmiah, karena karya ilmiah merupakan suatu karya yang dihasilkan mahasiswa sebagai tolok ukur intelektualitas mahasiswa (Hudhana, Wiharja, dan Fitriani, 2021:4). Makalah merupakan karya tulis ilmiah berisi infomasi atau bersifat faktual seperti yang diungkapkan oleh Suyitno (2012:27) bahwa makalah ilmiah adalah salah satu jenis karangan ilmiah yang ditulis secara sistematis dan logis berisi informasi atau data yang bersifat faktual yang disampaikan objektif dan tidak memihak pada kepentingan-kepentingan lain. Berdasarkan hal-hal yang telah dikemukakan tersebut, maka tujuan penelitian ini yaitu untuk mengkaji penggunaan ejaan bahasa Indonesia yang digunakan.

\section{B. METODE PENELITIAN}

Penelitian ini menggunakan metode penelitian kualitatif, penelitian dengan pendekatan kualitatif digunakan karena didasarkan pada jenis data yang akan dianalisis, yaitu data dalam penelitian bersifat kualitatif. Penelitian kualitatif digunakan apabila data yang diteliti berupa kata-kata atau verbal bukan berupa angka-angka yang harus menggunakan alat pengukur. Data dalam penelitian ini yaitu kesalahan ejaan pada makalah mahasiswa program studi Pendidikan Bahasa dan Sastra Indonesia. Sumber data penelitian ini yaitu makalah mahasiswa program studi Pendidikan Bahasa dan Sastra Indonesia. Teknik pengumpulan data penelitian ini menggunakan teknik catat yaitu peneliti mencatat kutipan data yang berkaitan dengan 
Lingua Rima: Jurnal Pendidikan Bahasa dan Sastra Indonesia

Vol. 10 No. 3 September 2021

http://jurnal.umt.ac.id/index.php/lgrm

kesalahan ejaan pada makalah mahasiswa. Teknik analisis data menggunakan teknik reduksi data, penyajian data dan penarikan simpulan.

\section{HASIL DAN PEMBAHASAN}

\section{Bentuk-Bentuk Kesalahan Ejaan Bahasa Indonesia pada Makalah}

a. Makalah ke-1 dengan judul "Membaca Nyaring"

1) Kesalahan pada penulisan kata asing

Pada data ke-1 pada kalimat yang berbunyi : Jadikanlah ini mengasyikkan, ekspresikanlah emosi-emosi yang dibangkitkan oleh cerita atau puisi dan bawalah sastra kedalam suasana yang hidup mellaui gerakan, sound effect, dan perubahan nada suara. Terdapat kesalahan tidak dimiringkan pada kata sound effect seharusnya kata tersebut dimiringkan karena ungkapan bahasa asing, peneliti menduga disebabkan oleh pertama karena tidak teliti yang kedua pengaruh grammar.

2) kesalahan pada penulisan kata depan

Data ke-1 Kesalahan penulisan kata yang terakhir yaitu menggabungkan penggunaan kata depan di dan kelas Hal ini ditemukan pada data kalimat yang berbunyi: Mulailah membacakan cerita pada awal pertama dikelas..... peneliti menduga, adaya kesalahan kecil di atas dapat disebabkan oleh 2 hal. Pertama, ketidaksengajaan penulis ketika mengetik. Kedua, faktor ketidakpahaman penulis dalam membedakan kata depan dan kata berimbuhan, kapan kata di dipisah penulisannya, dan kapan digabung penulisannya saat menuliskan kata. Kata yang keliru selanjutnya pada data ke-2 kata ke-dalam pada kalimat yang berbunyi : Jadikanlah ini mengasyikkan, ekspresikanlah emosi-emosi yang dibangkitkan oleh cerita atau puisi dan bawalah sastra kedalam suasana yang hidup melaui gerakan....

b. Makalah ke-2 dengan judul "Membaca Telaah Isi"

1) Hilangnya Vokal

Data ke-1 hilangnya vokal [e] di antara sebuah kata yang ditulis pada kata ketrampilan, penulis menduga pengilangan penulisan konsonan disebabkan ketidakseringan penulis dalam menulis konsonan pada kata keterampilan.

1) kesalahan pada huruf kapital

Data ke-1 yang berbunyi: BEBERAPA ASPEK MEMBACA KRITIS. Penulisan kosakata menggunakan huruf kapital hanya pada awal paragraf saja bukan pada kata kedua. Kosakata yang dimaksud terdapat pada kata yang secara rinci berbunyi: BEBERAPA ASPEK MEMBACA KRITIS menurut NURHADI:. Seharusnya, 
Lingua Rima: Jurnal Pendidikan Bahasa dan Sastra Indonesia

Vol. 10 No. 3 September 2021

http://jurnal.umt.ac.id/index.php/lgrm

penulisan huruf kapital hanya pada awal kalimat saja kata selanjutnya menggunakan huruf kecil saja menjadi Beberapa aspek membaca kritis menurut Nurhadi:. Data ke-2 pada kalimat Manfaat Membaca Ide sebagai berikut: kata membaca ide seharusnya menggunakan huruf kecil karena merupakan awal kalimat.

2) Kesalahan Penulisan Huruf Kecil

Pada Sub Bab yang berbunyi : a. Membaca teliti. Peneliti menemukan data ini pada bab II, Pada data ke-2, kesalahan awalan penulisan kosakata yang merupakan subbab melainkan kosakata yang menggunakan huruf kecil. Kosakata yang dimaksud terdapat pada kata teliti dalam subbab membaca telaah isi di bab II yang secara rinci berbunyi: 1. Membaca teliti 2. Membagi Pemahaman 3. Membaca Kritis Seharusnya, penulisan huruf kecil [t] tetap menggunakan huruf kapital karena Pada data ke-2, kesalahan awalan penulisan kosakata urutan kedua subbab menggunakan huruf kecil. peneliti menduga, kesalahan penulisan huruf kecil pada kedua subbab yang ada di bab II tersebut karena mereka hanya menuliskan kebiasaan yang mereka tuliskan tanpa pernah bertanya atau mencari tahu alasannya kenapa harus menggunakan huruf kapital untuk awalan kosakata yang ada di setiap subbab, serta tidak terlalu memahaminya. Mereka fokus pada substansi penelitian masing-masing daripada formatnya. Padahal, setiap awalan kosakata yang ditulis di subbab dan tidak diakhiri dengan pemarkah titik (.), tidak ditulis menggunakan huruf kecil melainkan huruf kapital.

3) Hilangnya Tanda Baca

Pada BAB 3 Penutup terdapat saran, kesalahan penulisan ditemukan pada hilangnya tanda baca titik (.) di akhir kalimat. Hal ini dapat diamati pada data kalimat yang berbunyi: Berdasarkan kesimpulan dapat disimpulkan saran sebagai berikut: 1 . Kita harus lebih meningkatkan keterampilan membaca dan uraian poin ke-dua sampai ke-empat semua tidak ada tanda baca titik. Peneliti beranggapan bahwa kesalahan penulisan kata dengan menghilangkan tanda baca ini juga disebabkan faktor lupa dan tergesa-gesa.

c. Makalah ke-3 dengan judul "Penelitian Fokus dalam Membaca"

1) Kesalahan penulisan kata berimbuhan

Pada makalah ke-3 data ke-1 kesalahan ini muncul pada kata pengantar yang digunakan penulis ketika menulis kata di susun pada kalimat yang berbunyi: Makalah ini di susun untuk memenuhi tugas mata kuliah Pendidikan Pancasila dengan pembahasan FOKUS DALAM MEMBACA" Penulis salah menuliskan nama mata 
Lingua Rima: Jurnal Pendidikan Bahasa dan Sastra Indonesia

Vol. 10 No. 3 September 2021

http://jurnal.umt.ac.id/index.php/lgrm

kuliah kemudian salah dalam menuliskan kata di susun seharusnya disusun disatukan tulisannya karena ini merupakan imbuhan dan awalan yang dihubungkan antara imbuhan di dengan kata dasar susun maka terbentuklah disusun. Data ke-2 yaitu kata di berikan pada kalimat yang berbunyi: Ucapan terimakasih.......semoga beliau senantiasa di berikan kesehatan....kesalahan penulis dalam membedakan kata depan di kapan dipisah dan kapan digabungkan. Data ke-3 pada kata hasil nya pada kalimat yang berbunyi : Hasil nya dengan menggunakan metode informasi fokus seorang pembaca akan lebih cepat ...seharusnya akhiran ini serangkai dengan bentuk dasarnya menjadi hasilnya.

2) kesalahan pada huruf kapital

Data ke-1 pada bab II Pembahasan yang berbunyi: Informasi fokus merupakan Semua....Penulisan kosakata menggunakan huruf kapital hanya pada awal paragraf saja bukan pada kata selanjutnya. Kosakata yang dimaksud terdapat pada kata yang secara rinci berbunyi: Informasi fokus merupakan Semua informasi yang terdapat dalam suatu bacaan merupakan pengetahuan,.... Seharusnya, penulisan huruf kapital hanya pada awal kalimat dan kata selanjutnya menggunakan huruf kecil saja. Data ke2 pada Paragraf pertama kalimat pertama yang berbunyi : Perlu diketahui Informasi

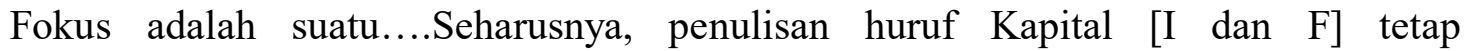
menggunakan huruf kecil bukan huruf kapital karena, huruf kapital cukup diletakkan pada awal kalimat saja tidak semuanya.

3) Hilangnya Vokal dan konsonan

Data ke-1 hilangnya vokal [e] di antara sebuah kata yang ditulis pada kata kecendrungan, penulis menduga pengilangan penulisan konsonan disebabkan ketidakseringan penulis dalam menulis konsonan pada kata kecendrungan.

4) Kosakata Asing Muncul karena Pengaruh Grammar

Kesalahan penulisan kata yang lain yakni kemunculan kosakata asing karena pengaruh grammar yang ter-setting bahasa Inggris di laptop salah satu mahasiswa. Akibatnya, ada beberapa kosakata yang seharusnya sudah tertulis tepat menggunakan bahasa Indonesia berubah seketika menjadi bahasa Inggris. Misalnya, kata fokus menjadi focus.

5) Hilangnya Tanda Baca

Data ke-1 pada BAB 1 tujuan penelitian terdapat tujuan pada no 1 yaitu mencari teknik teknik, kesalahan penulisan ditemukan pada hilangnya tanda hubung (-) untuk 
Lingua Rima: Jurnal Pendidikan Bahasa dan Sastra Indonesia

Vol. 10 No. 3 September 2021

http://jurnal.umt.ac.id/index.php/lgrm

menggabungkan kata ulang. Hal ini dapat diamati pada data kalimat yang berbunyi: mencari teknik teknik informasi fokus. Peneliti beranggapan bahwa kesalahan penulisan kata dengan menghilangkan tanda baca ini juga disebabkan faktor lupa dan tergesa-gesa. Data ke-2 pada bab III kalimat saran yang berbunyi: Harus kita tingkatkan keinginan dan kemauan didalam membaca dengan menggunakan informasi fokus seharusnya pada akhir kalimat itu terdapat tanda baca titik.

6) Penggunaan Kata Depan

Data ke-1 muncul pada kesalahan bab III penutup pada kalimat kesimpulan berbunyi: ........yang akan dibaca mengenai topik dan hal yang terkait didalam kebutuhan. Dan kesalahan pada kalimat saran yang berbunyi: Harus kita tingkatkan keinginan dan kemauan didalam membaca dengan menggunakan informasi fokus seharusnya kata didalam dipisahkan karena merupakan kata depan bukan imbuhan yang harus ditulis serangkai.

d. Makalah ke-4 dengan judul Pemahaman dan Membaca Efisien

Penggunaan Huruf Kapital pada Gelar, Pangkat atau Sapaan dan Dipakai sebagai Huruf Pertama Awal Kalimat

Data ke-1 muncul pada kesalahan pada kata pengantar yang berbunyi: Terima kasih juga saya sampaikan kepada dosen pengampu Hera Wahdah Humaira, M.pd yang membantu dalam menyelesaikan makalah ini. Seharusnya penulisan huruf kapital pada huruf pertama singkatan gelar menjadi M. Pd. Data ke-2 kesalahan huruf kapital ditengah kalimat misalnya pada penggalan kalimat: a) Kemampuan mengingat dan mengenali Kemampuan mengingat dan mengenali meliputi kemampuan. Seharusnya huruf $(\mathrm{k})$ pada kalimat tersebut menggunakan huruf kecil.

1) Hilangnya Tanda Baca

Data ke-1 dan ke-2 tidak ada tanda petik dua yang dipakai untuk mengapit judul sajak, lagu, film, sinetron, artikel, naskah, atau bab buku yang dipakai dalam kalimat. Hilangnya tanda baca tersebut yaitu pada kalimat yang berbunyi: Makalah ini membahas tentang Penerapan Meningkatkan Kemampuan Membaca Pemahaman dan Membaca Efisien. Seharusnya tanda baca petik dua mengapit judul tersebut menjadi "Penerapan Meningkatkan Kemampuan Membaca Pemahaman dan Membaca Efisien”. Data ke-3 dan ke-4 hilangnya tanda baca titik pada kalimat contoh: khususnya dalam pembelajaran membaca pemahaman diakhiri tanda titik menjadi khususnya dalam pembelajaran membaca pemahaman. 
Lingua Rima: Jurnal Pendidikan Bahasa dan Sastra Indonesia

Vol. 10 No. 3 September 2021

http://jurnal.umt.ac.id/index.php/lgrm

2) Tidak Ada Spasi setelah Tanda Baca

Data ke-1 Kesalahan ketiga dari penulisan tanda baca adalah tidak dispasinya tanda baca baik berupa titik (.) maupun koma (,) dengan kata yang mengikutinya di depan. Data penelitian berupa tanda titik (.) jauh dibelakang kalimat, ditemukan dalam penggalan kalimat: Ide pokok terdapat dalam setiap paragraf .biasanya, ide pokok dinyatakan secara eksplisit. Ke dua kalimat ini memiliki spasi dua ketukan sehingga jauh dari kalimatnya. Data ke-2 tidak ada spasi setelah tanda baca titik dua (:) pada kalimat yang berbunyi: sedangkan paragraf:suatu bahasa yang lebih besar dari pada....kalimat ini tentu saja keliru sehingga membuat kalimatnya menjadi cepat dibacanya. Data ke-3 pada penggalan kalimat: ...yang mana merupakan ide pokok.Akan tetapi, mengetahui detail saja tidak cukup...Peneliti beranggapan bahwa kesalahan ini disebabkan oleh tergesa-gesanya penulis dalam proses pengetikan tanpa adanya penyeleksian kembali hasil tulisan yang sudah dibuat.

3) Kesalahan penulisan kata berimbuhan

Pada bab 2 makalah ke-4 data ke-1 dalam kesalahan ini muncul pada kalimat yang berbunyi: Anda mesti mengambil intisari atau rangkuman dari tiap-tiap pelajaran yang telah di baca lagi. Penulis salah menuliskan kata di baca menjadi ditulis terpisah seharusnya ditulis serangkai dengan kata dasarnya.

e. Makalah ke-5 dengan judul "Membaca Paragraf dan Membaca Artikel"

1) Hilangnya Tanda Baca

Pada tabel ke-1, kesalahan penulisan ditemukan pada hilangnya tanda hubung (-) untuk menggabungkan bentuk pengulangan kata. Hal ini dapat diamati pada data kalimat yang berbunyi: Paragraf merupakan himpunan dari kalimat kalimat yang bertalian dalam suatu rangkaian untuk membentuk suatu gagasan..

2) kesalahan pada huruf kapital

Data ke-1 pada bab II Pembahasan yang berbunyi: Ciri-ciri paragraf a) paragraf menggunakan pikiran utama yang dinyatakan dalam kalimat topik. b) setiap paragraf menggunakan satu kalimat topik, selebihnya merupakan kalimat Penjelas dalam memguraikan kalimat topik. Kata penjelas pada huruf (P) Seharusnya huruf kecil karena penulisan huruf kapital hanya pada awal kalimat dan kata selanjutnya menggunakan huruf kecil saja. Data ke-2 pada kalimat berikut ini: Jadi Artikel adalah.... seharusnya Jadi artikel adalah sehingga menjelaskan bahwa huruf kapital hanya pada awal kalimat. 
Lingua Rima: Jurnal Pendidikan Bahasa dan Sastra Indonesia

Vol. 10 No. 3 September 2021

http://jurnal.umt.ac.id/index.php/lgrm

3) Hilangnya Vokal dan konsonan

Data ke-1 pada kalimat yang berbunyi: Ciri-ciri paragraf a) paragraf menggunakan pikiran utama yang dinyatakan dalam kalimat topik. b) setiap paragraf menggunakan satu kalimat topik, selebihnya merupakan kalimat Penjelas dalam memguraikan kalimat topik. kata memguraikan pada konsonan $m$ seharusnya dengan huruf $n$ sehingga menjadi menguraikan, penulis menduga pengilangan penulisan konsonan disebabkan ketidakcermatan dan ketidaktelitiaan dari penulis.

4) Kesalahan penulisan kata asing

Kesalahan penulisan kata asing dengan menggunakan huruf tegak bukan miring juga ditemukan dalam makalah ke-5 ini.. Kosakata tersebut antara lain: di-download penulisannya tidak dimiringkan seharusnya download dan kata di seharusnya imbuhan dan serangkai dengan kata dasarnya dan berbahasa Indonesia bukan untuk kata asing.

5) Kesalahan penulisan kata berimbuhan

Pada bab 2 makalah ke-5 data ke-1 dalam kesalahan ini muncul pada kalimat yang berbunyi: Dari keseluruhan pendapat, dapat di simpulkan bahwa artikel merupakan karangan faktual secara lengkap...... Penulis salah menuliskan kata di simpulkan menjadi ditulis terpisah seharusnya ditulis serangkai dengan kata dasarnya menjadi disimpulkan.

6) Tidak Ada Spasi setelah Tanda Baca

Pada perincian langkah-langkah menulis artikel pada perincian no.4 yang berbunyi: 4. Buat tulisan yang langsung pada point. Banyak orang tidak punya banyak waktu untuk membaca di internet.Oleh karena itu....tidak ada spasi setelah kata internet seharusnya setelah kata internet ada tanda baca selanjutnya spasi.

7) Penggunaan Kata Depan

Data ke-1 muncul pada kesalahan bab III penutup pada kalimat kesimpulan berbunyi: Sehingga dengan adanya fungsi diatas serta dengan adanya artikel dapat mengkritik para sastrawan.... . kata diatas seharusnya ditulis di atas dipisahkan karena kata di adalah kata depan. Dan kesalahan pada kalimat saran yang berbunyi: Harus kita tingkatkan keinginan dan kemauan didalam membaca dengan menggunakan informasi fokus seharusnya kata didalam dipisahkan karena merupakan kata depan bukan imbuhan yang harus ditulis serangkai

8) Penulisan kata partikel 
Data ke-1 partikel pun pada bab III penutup dalam kesimpulan berbunyi: Artikel juga memiliki tujuan-tujuan tersendiri, yang setiap tujuannya memiliki pengertian dan fungsi-fungsinyapun juga berbeda partikel pun pada kalimat ini disatukan seharusnya dipisah dari kata yang mendahuluinya menjadi fungsi-fungsinya pun.

9) Penulisan Huruf Miring

Data ke-1 dalm daftar pustaka terdapat kesalahan penulisan judul buku tidak menggunakan huruf miring pada penggalan kalimat berikut ini: Finoza,L. 2007-2008. Komposisi Bahasa Indonesia untuk Mahasiswa Nonjurusan Bahasa. Cetakan XII. Jakarta: Diksi Insan Mulia. Judul tersebut tidak dituliskan miring seharusnya menggunakan huruf miring.

f. Makalah ke-6 dengan judul "Membaca dengan Teknik Skimming dan Scanning"

1) Hilangnya Tanda Baca

Pada data ke-1, kesalahan penulisan ditemukan dalam kata pengantar pada hilangnya tanda titik untuk mmengakhiri kalimat. Hal ini dapat diamati pada data kalimat yang berbunyi: Semoga makalah ini dapat bermanfaat sebagaimana mestinya. Kritik dan saran yang membangun sangat kami harapkan guna memperbaiki makalah ini (.). Tidak terdapat tanda titik pada akhir kalimatnya. Data ke-2 hasil penelitian pada uji data kemampuan menemukan informasi dalam kamus dengan cepat. Pada kalimat yang dituliskan oleh penulis tidak ada titik dalam mengakhiri kalimatnya misalnya pada penggalan kutipan berikut: Nama Siswa: Silvia Putri Hasil: 4 kata dalam waktu 3 menit. Belum mampu menemukan ide pokok secara keseluruhan (.) harusnya ada tanda (.) untuk mengakhiri kalimatnya.

2) Penggunaan Kata Depan

Data ke-1 muncul pada kesalahan bab I pada paragraf kedua pada kalimat yang berbunyi: Membaca adalah sebuah keterampilan yang dimana setiap orang berbedabeda kemampuan membacanya. Seharusnya kata yang dimana dipisahkan menjadi di mana karena merupakan kata depan bukan imbuhan yang harus ditulis serangkai akan tetapi kata ini tidak tepat digunakan dalam kalimat ini. Tetapi kata di mana digunakan untuk kalimat pertanyaan.

3) Makalah ke-7 dengan judul "Membaca Surat Kabar"

1) Kesalahan penulisan kata berimbuhan

Pada bab I Pendahuluan paragraf kedua data ke-1 pada kalimat yang berbunyi: ...yang kesemuanya saling berkaitan.... Penulis salah menuliskan kata semuanya 
Lingua Rima: Jurnal Pendidikan Bahasa dan Sastra Indonesia

Vol. 10 No. 3 September 2021

http://jurnal.umt.ac.id/index.php/lgrm

menjadi ditulis kesemuanya seharusnya ditulis semuanya karena imbuhan ke- dengan kata dasar semuanya bermakna tidak jelas sedangkan semuanya maknanya segalagalanya.

2) Tidak Ada Spasi setelah Tanda Baca

Data ke-1 Kesalahan kedua dari penulisan tanda baca adalah tidak dispasinya tanda baca berupa titik (.) dengan kata yang mengikutinya di depan. Data penelitian berupa tanda titik (.) tidak dispasi pada kalimat selanjutnya, ditemukan dalam penggalan kalimat: 4. Teknik membaca iklan dan pemberitahuan adalah baca layap dan baca tatap.Berdasarkan pedapat di atas,...Peneliti beranggapan bahwa kesalahan ini disebabkan oleh tergesa-gesanya penulis dalam proses pengetikan tanpa adanya penyeleksian kembali hasil tulisan yang sudah dibuat.

3) Penggunaan Kata Depan

Data ke-1 pada paragraf ke-3 dalam penggalan kalimat: Pembahasan mengenai materi tersebut akan dibahas didalam makalah kami. Seharusnya kata didalam dipisah menjadi di dalam karena penulisan di sebagai kata depan penunjuk tempat yang harus ditulis terpisah.

4) Makalah ke-8 dengan judul "Metode Mengembangkan Kecepatan Membaca"

1) Hilangnya huruf vocal dan konsonan

Data ke-1 hilangnya vokal [i] dan huruf onsonan [d) pada kata tidak di antara sebuah kata yang ditulis pada kalimat yang berbunyi: Tak lupa salawat dan salam...., seharusnya tidak lupa salawat dan salam...penulis menduga pengilangan penulisan vocal dan konsonan disebabkan penggunaan bahasa gaul yang digunakan penulis sehari-hari.

2) Kesalahan penulisan kata berimbuhan

Pada kata pengantar makalah ke-8 data ke-1 dalam kesalahan ini muncul pada kalimat yang berbunyi: Makalah ini di susun untuk memenuhi tugas.... Penulis salah menuliskan kata di susun menjadi ditulis terpisah seharusnya ditulis disusun serangkai dengan kata dasarnya. Data ke-2 bab II dalam penggalan kalimat: yang barangkali di dukung... seharusnya kata di ditulis serangkai dengan kata dukung menjadi didukung. Data ke-3 pada bab III kesimpulan pada kalimat yang berbunyi: Metode yang $d i$ anggap efektif dalam meningkatkan kecepatan membaca adalah: a. Metode kosa kata....seharusnya imbuhan di bertemu dengan kata dasar anggap ditulis serangkai menjadi kata dianggap. 
Lingua Rima: Jurnal Pendidikan Bahasa dan Sastra Indonesia

Vol. 10 No. 3 September 2021

http://jurnal.umt.ac.id/index.php/lgrm

3) Kesalahan penulisan kata asing

Kesalahan penulisan kata asing diakibatkan salah ketik juga ditemukan dalam makalah ke-8 ini.. penggalan kalimat tersebut antara lain: Caranya adalah dengan membaca paragraph. Seharusnya kata paragraph ditulis berbahasa Indonesia menjadi paragraf bukan kata asing.

5) Makalah ke-9 dengan judul "Membaca dalam Hati"

1) Kesalahan Penulisan Huruf Kecil

Pada data ke-1 bab II pada kalimat yang berbunyi : ... sehingga memperoleh serta memahami ide-ide dengan usahanya sendiri.harus disadari.... Kata harus sebaiknya menggunakan huruf kapital karena dipakai sebagai huruf pertama setiap kata. Peneliti menduga adanya kesalahan pada penulisan huruf kecil disebabkan oleh pertama karena tidak teliti dan tergesa-gesa.

2) Hilangnya Tanda Baca

Pada data ke-1, kesalahan penulisan ditemukan dalam pembahasan bab II pada hilangnya tanda titik untuk mmengakhiri kalimat. Hal ini dapat diamati pada data kalimat yang berbunyi:Dia akan menguasai cerita-cerita dan uraian-uraian sebagai suatu keseluruhan yang dalam kegiatan membaca nyaring ini hanya dapat memahami fragmen-fragmen yang hanya lepas-lepas saja (.). Tidak terdapat tanda titik pada akhir kalimatnya. Data ke-2 pada kalimat:....dan juga saran-saran linguistic yang dipergunakan untuk mencapai tujuan tanpa adanya tanda titik sebagai akhir dari kalimat.

3) Penggunaan Kata Depan

Data ke-1 pada sub pokok bahasan tentang membaca intensif pada paragraf ke-3 dalam penggalan kalimat: ...terperinci terhadap tanda-tanda diatas kertas. Seharusnya kata diatas dipisah menjadi di atas karena penulisan di sebagai kata depan penunjuk tempat yang harus ditulis terpisah.

4) Kesalahan penulisan kata asing

Data ke-1 Kesalahan penulisan kata asing diakibatkan salah ketik juga ditemukan dalam makalah ke-9 ini.. penggalan kalimat tersebut antara lain: Tujuan utama adalah untuk memperoleh sukses dalam pemahaman penuh terhadap argument-argumen... seharusnya kata argument ditulis argument yang artinya alasan sehingga bukan ditulis menjadi kata asing. Data ke-2 pada kalimat: ...dan juga saran-saran linguistic..., seharusnya kata linguistic yang benar menjadi linguistik. 
Lingua Rima: Jurnal Pendidikan Bahasa dan Sastra Indonesia

Vol. 10 No. 3 September 2021

http://jurnal.umt.ac.id/index.php/lgrm

5) Hilangnya huruf vocal dan konsonan

Data ke-1 hilangnya vokal [i] dan[a] pada kata hasul-hasilnya di antara sebuah kata yang ditulis pada kalimat yang berbunyi: Tetapi hasul-hasilnya dalam hal ini...., seharusnya kalimatnya menjadi tetapi hasil-hasilnya dalam hal ini... kata keliru selanjutnya pada kalimat:...,suatu pemahman yang mendalam...seharusnya pemahaman. Penulis menduga pengilangan penulisan vocal ini disebabkan salah ketik yang dilakukan penulis.

6) Tidak Ada Spasi setelah Tanda Baca

Data ke-1 Kesalahan kesatu dari penulisan tanda baca adalah tidak dispasinya tanda baca berupa titik (.) dengan kata yang mengikutinya di depan. Data penelitian berupa tanda titik (.) tidak dispasi pada kalimat selanjutnya, ditemukan dalam penggalan kalimat: 1. ...halaman setiap hari.Kuesioner, 2. ...diutamakan atau yang paling menarik perhatian kita,tetapi, 3. ...dalam hal ini suatu pengertian,suatu pemahman...4. Biasanya...berupa teks yang amat singkat.Membaca. Data ke-2 kesalahan kedua dari penulisan tanda baca koma adalah tidak dispasinya tanda baca (,) dengan kata yang mengikutinya misalnya pada penggalan kalimat:1. Biasanya,bahan untuk pemahaman....,2. ....argument-argumen yang logis,urutan-urutan retoris atau pola-pola teks,pola-pola simbolisnya;nada-nada tambahan yang bersifat emosionaldan sosial,pola-pola.

6) Makalah ke-10 dengan judul "Meningkatkan Kecepatan dan Keefektifan Membaca"

1) Penggunaan Kata Depan

Data ke-1 pada kata pengantar dalam penggalan kalimat: Kami menyadari sekali, didalam penyusunan makalah ini.... Seharusnya kata didalam dipisah menjadi di dalam karena penulisan di sebagai kata depan penunjuk tempat yang harus ditulis terpisah.

2) Kesalahan penulisan kata berimbuhan

Pada bab II data ke-1 sub pokok bahasan teknik membaca cepat dan efektif, dalam kesalahan ini muncul pada kalimat yang berbunyi: dalam kehidupan sehari-hari membaca merupakan suatu kebutuhan pokok yang harus di penuhi, tiada hari tanpa membaca. Penulis salah menuliskan kata di penuhi menjadi ditulis terpisah seharusnya ditulis disatukan menjadi dipenuhi serangkai dengan kata dasarnya.

\section{SIMPULAN DAN SARAN}


Lingua Rima: Jurnal Pendidikan Bahasa dan Sastra Indonesia

Vol. 10 No. 3 September 2021

http://jurnal.umt.ac.id/index.php/lgrm

Simpulannya dalam penelitian ini adalah bahwa mahasiswa melakukan kesalahan dalam penggunaan ejaan disebabkan kurangnya pengetahuan mereka tentang isi dari pedoman ejaan bahasa Indonesia (PUEBI) dan juga kurangnya pengetahuan tentang kosakata bahasa Indonesia. Ini akan berakibat pada penggunaan bahasa yang baik dan benar pada kaya tulis makalah mahasiswa. Penyebab utama kesalahan pada makalah mahasiswa yaitu penggunaan huruf kapital, hilangnya tanda baca, tidak ada spasi setelah tanda baca, hilangnya vocal dan konsonan, kesalahan penulisan kata asing pada makalah yaitu salah ketik, tidak teliti dan tergesa-gesa. Banyaknya kesalahan mahasiswa dalam kata berimbuhan, kata depan, kata partikel dan huruf miring disebabkan karena mahasiswa belum menguasai pedoman ejaan bahasa Indonesia (PUEBI) dan terkadang lupa membedakan kata dalam bahasa Indonesia. Kami menyarankan untuk menambah kosakata dan terus memberikan latihan kepada mahasiswa untuk mengembangkan pengetahuan bahasa Indonesia. Penelitian ini dapat diharapkan untuk pengembangan ilmu dan dapat dimanfaatkan sebagai refrensi penelitian selanjutnya.

\section{E. DAFTAR PUSTAKA}

Gantametrika dkk. (2016). Kesalahan Berbahasa Penggunaan EYD. Solo: Genta Smart Publisher.

Hudhana, Winda D, Wiharja, Irpa A, dan Fitriani, Hamdah S. H. (2021). Bentuk Kesalahan Kalimat dalam Karya Ilmiah Mahasiswa BIPA Thailand. Jurnal Lingua Rima. Vol 10 No 2 Halaman 43-50

Siswoyo, D. (2007). Ilmu Pendidikan. Yogyakarta: UNY Press.

Suyanto, E. (2011). Membina, Memelihara dan Menggunakan Bahasa Indonesia Secara Baik dan Benar. Yogyakarta: Ardana Media.

Suyitno, I. (2012). Menulis Makalah dan Artikel (Teori, Contoh dan Praktik Perlatihan). Bandung: PT Refika Aditama.

Wijayanti, S. H., dkk. (2013). Bahasa Indonesia: Penulisan dan Penyajian Karya Ilmiah. Jakarta: PT Raja Grafindo Persada. 